\title{
Research on the Relationship between Information Communication Technology Investment, Total Factor Productivity and Economic Growth: Literature Review and Prospects
}

\author{
Wei Qiying \\ School of Economics \\ Central University of Finance and Economics \\ China Economic Information Service \\ Beijing, China, 100081
}

\begin{abstract}
It is found by sorting relevant literatures that, as the research deepens and the information level rapidly develops, more and more scholars affirm the promotion effect of information communication technology (ICT) investment on total factor productivity (TFP) and economic growth. In the meantime, however, there is "productivity paradox" as well. ICT investment is influenced by time delay effect, measuring error and insufficient capital stock. There are "productivity paradox" of ICT to certain extent in countries and regions with different development levels, which features stage characteristics and threshold effects. When the development of ICT breaks through this threshold, the "productivity paradox" disappears, and the contribution of ICT investment to TFP and economic growth will be gradually highlighted.
\end{abstract}

Keywords: ICT; TFP; Productivity Paradox; Economic Growth

\section{Preface}

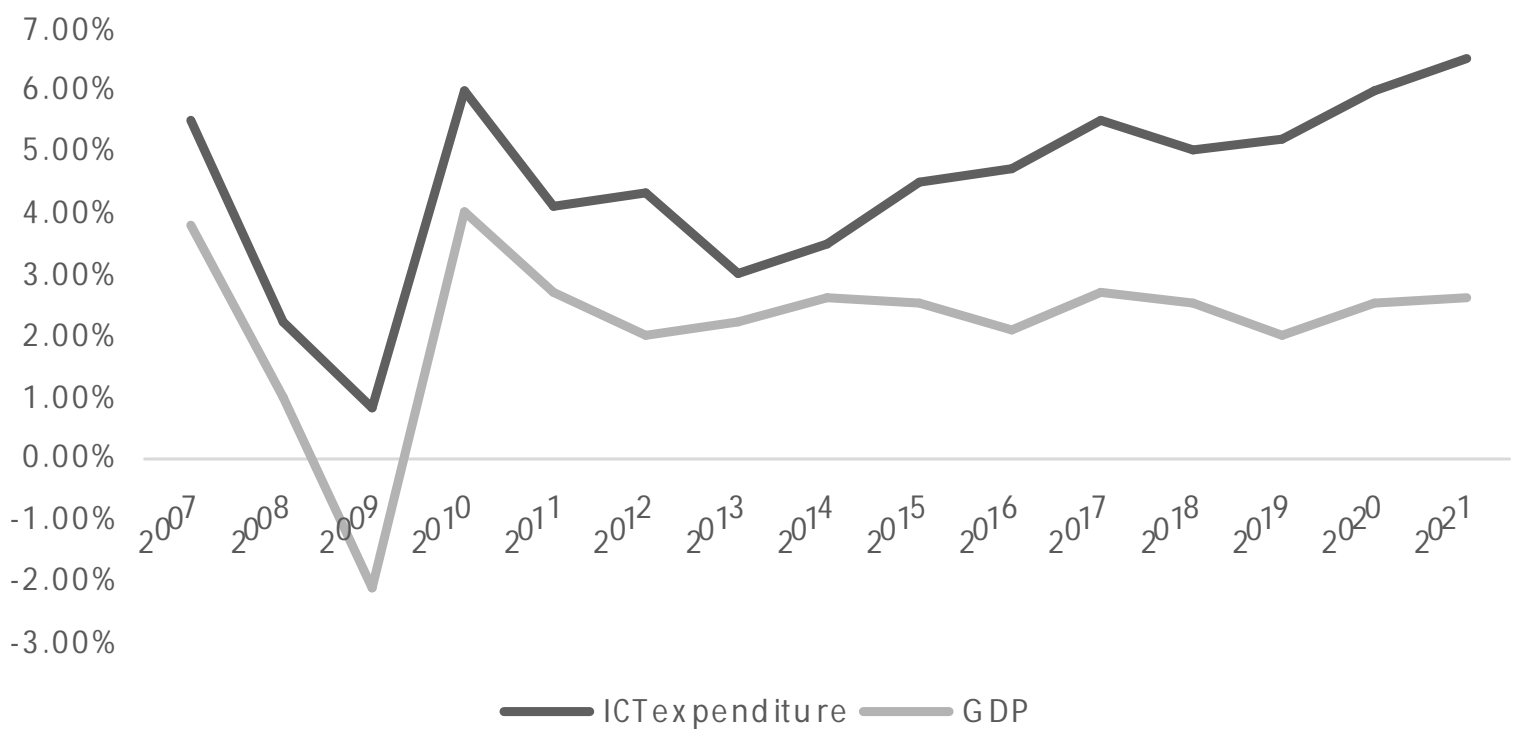

Data source: IDC

Figure 1. 1 Comparison of global ICT expenditure and GDP

Over the past decades, Information Communication Technology (ICT) has accelerated its penetration in all aspects of the economic society, constantly affecting the changes of such fields as banking, retail, education and medical care. According to IDC's data, in recent years, countries across the globe attach increasing attention to ICT, with greater investment made there for. Expenditure on ICT has grown steadily at a compound rate of $6 \%$ a year, with global ICT expenditure totaling USD 4.54 trillion in 2017. It is expected that the U.S., the largest contributor to ICT expenditure, will invest USD 1.3 trillion in research and development of ICT applications in 2018. 
However, since Solow put forward the "productivity paradox" in 1987 (i.e. the increase of ICT investment does not significantly promote economic growth and increase of the TFP, or even slow down the increase of the TFP), researches on "productivity paradox" and performance of ICT investment have gradually become one of the most important topics in academic circles. At present, academic circles 'researches on the influence of ICT investment on TFP and economic growth can be divided into two groups: first, relevance of ICT investment, i.e. it affirms the promotion effect of ICT investment on TFP and economic growth; second, irrelevance of ICT investment, i.e. it denies the promotion effect of ICT investment on TFP and economic growth. In the sections below, we will analyze and summarize the relevant studies on "productivity paradox" and performance of ICT investment in developed and developing countries to clarify the present development stage of ICT.

\section{Analysis on the Effect of ICT Investment on Economic Growth}

OECD (2003) ${ }^{[1]}$ analyzes the channel how ICT investment promotes the economic growth. There are mainly three channels: first, ICT investment drives the decline of product price, which will further promote the capital accumulation, realizecapital deepening and improve the productivity, thus boosting the economic growth. Second, the increasing ICT investment boosts the technological progress and efficiency improvement, and improves the growth of the TFP, thus affecting the overall economy. Third, as the ICT investment increases, the benefits of spillover effect will gradually enhance, which will lead to the increase of the TFP of other sectors, thus finally boosting the growth of national economy as a whole. This paper affirms the promotion effect of ICT investment on TFP and economic growth, which can be called "theory on relevance of ICT investment."

\section{(I) ICT investment drives capital deepening and boosts economic growth}

Jorgenson and Stiroh (2000) ${ }^{[2]}$ found that the U.S. economy has witnessed obvious improvement in labor productivity and TFP since 1995, mainly due to computer, software, communications technologies and other ICT products. In the meantime, the increase of productivity drives the decline of relative price of ICT products and attracts a lot of investments, making technological progress and capital deepening the main factors driving the growth of the U.S. economy, and keeping sustainable growth. Oliner and Sichel (2002) ${ }^{[3]}$ found that the average growth rate of labor productivity in the U.S. from 1996 to 2001 was $2.43 \%, 1.02 \%$ of which were contributed by the deepening of ICT capital. They argue that the sharp drop in prices of ICT products in the U.S. since 1995 has led to a sharp increase of ICT investment and a significant increase of its share of total capital. Jorgensen et al. (2003) ${ }^{[4]}$ used the theory of "capital deepening" to explain the reason why the U.S.'s productivity increased from $1.33 \%$ in $1975-1993$ to $2.07 \%$ in 1995-2000. On the one hand, from 1995 to 2000, ICT capital deepening increased from $0.37 \%$ to $0.87 \%$, while other capital deepening decreased from $0.43 \%$ to $0.37 \%$. On the other hand, due to the overheated economy between 1995 and 2000, it is easy to find jobs, and labor quality declined. The productivity generated by ICT investment increased from $0.21 \%$ in 1995 to $0.45 \%$ in 2000 , while the productivity associated with other capitals increased from $0.05 \%$ to $0.17 \%$ in the same period. Thus, it can be seen that the rapid growth of the U.S.'s productivity from 1995 to 2000 was almost entirely due to ICT investment.

\section{(II) ICT investment promotes the TFP growth of the department and boosts the economic growth}

Jorgenbonetal (2008) ${ }^{[6]}$ conducted a phased analysis on the impact of ICT investment on productivity growth in the U.S. from 1959 to 2006. It is found that during the period from 1995 to $2000,2.7 \%$ of the productivity growth of ICT in the U.S. mainly comes from the R \& D and manufacturing sectors of ICT, especially computer \&office equipment, computer services, electronic components and communication equipment which only account for 3\% of GDP but contribute $25 \%$ of the growth rate (the non-ICT industry, which accounts for $70 \%$ of economic added value, contributed only $50 \%$ of the growth rate). Hawash and Lang (2010) ${ }^{[7]}$ studied whether the developing countries can improve the TFP by increasing the ICT investment on the basis of empirical tests for data from 33 developing countries from 2002 to 2006. It is found that the ICT investment expenditure can significantly promote the growth of the TFP, but the relationship between the two is of "inverted U" type. The optimal annual growth rate for ICT expenditure is $23 \%$, compared with $13.23 \%$ on average in developing countries, resulting in slow growth in TFP. However, it also shows that developing countries have enormous development space and potential in optimizing the efficiency of ICT investment and realizing economic growth.

\section{(III) Spillover effect of ICT investment boosts economic growth}

In view of the limited contribution of ICT sector to economic growth, Rekey (2008) considers that the indirect effects of ICT investment on economic growth are greater than its direct effects. These indirect effects are called ICT penetration. 
This kind of penetration is embodied in the ICT infrastructure investment as a kind of social capital, which can facilitate the communication of information, reduce the business transaction cost, improve the organization efficiency, form spillover effect and positive externality, thus improving the overall production efficiency. Chang and Gurbaxani (2012) ${ }^{[8]}$ studied the strength and duration of ICT spillover effect and its long-term impact on productivity improvement from a long-term perspective, and found that the ICT service industry benefits greatly from the spillover effect of ICT for a long time. In the meantime, high-ICT-intensive companies benefit more from the externalities brought about by technology spillover for about 10 years. The investment and development of ICT greatly promote the diffusion of technology spillover effect, while the technology spillover effect of lowICT-intensive companies can only last for about four years.

Huangetal (2013) ${ }^{[9]}$ points out that ICT features strong knowledge spillover effect, which can promote the increase of productivity. They divided spillover effect into two different types: first, from technical knowledge (main includes such expertise fields as operating systems, programming languages and database management systems); second, from business functions (emphasis on changes in organizational and business processes driven by ICT). The latter is often the main factor in determining whether companies will benefit from ICT investment, but it is often too costly and difficult. Therefore, promoting the flowing of technology knowledge can bring the knowledge spillover effect of ICT into full play, thus improving the enterprise's performance. In balance, it is the increase of ICT investment that boosts the growth of the TFP and drives the economic growth whether it is due to the deepening capital driven by decline in the price of ICT products, or technological progress and improvement of departmental efficiency boosted by innovation in ICT, or the spillover effect of ICT investment.

\section{Formation and Development of Productivity Paradox}

ICT "productivity paradox" refers that the increase of ICT investment does not significantly promote economic growth and increase of the TFP, or even slow down the increase of the TFP of some departments, and that increase of the TFP brought by ICT investment is not as obvious as that brought by non-ICT investment, with little contribution to the overall economic growth. It denies the promotion effect of ICT investment on TFP and economic growth, which can be called "theory on irrelevance of ICT investment" here. Since Solow put forward the "ICT Productivity Paradox "in 1987, the academic research and debate on it has been going on up to now. The scope of researches on "ICT Productivity Paradox" keeps expanding and its contents are continuously deepened from the debate and explanation of the existence of the paradox in the late 1980s to the query of the paradox with the development of ICT in middle 1990s, to the re-examination of the growth effect of ICT investment after the bursting of the Internet bubble in early 21 st century.

\section{(I) Formation of ICT Productivity Paradox}

From the mid-1980s to the early 1990s, the mainstream academic circles generally believed that ICT investment contributes little to the TFP and economic growth. Some academic researches even found that the ICT investment is negatively correlated to the increase in TFP. Roach (1987) ${ }^{[10]}$ studied productivity growth and computer applications over the seven years from 1977 to 1984. It is found that there was no relationship between the growth of large numbers of computers in American enterprises and the improvement of economic performance. In the same period, Solow (1987) ${ }^{[11]}$ calculated the correlation between the ICT investment and the TFP. The data shows that, from 1949 to 1973, labor productivity and TFP increased by 2.9\% and 1.9\% respectively. During 1973 to 1999 , the ICT was widely applied in all fields of economy, but the TFP was reduced from $1.1 \%$ to $0.2 \%$. The famous "Solow Paradox" or "Productivity Paradox" also came into being, that is, "computers function well for all fields except for productivity statistics." "Productivity paradox"aroused heated discussion and even controversy in the field of economics once it was proposed. Many scholars studied the reliability and rationality of the paradox from multiple aspects. Berndt and Morrison (1992) ${ }^{[12]}$ found via researches that, from 1968 to 1986,every 1 dollar of ICT investment can bring only 80 cents marginal value, indicating that the ICT industry suffers excessive investment. In 1994, they applied a large number of identical data for analysis and found that there was a significant negative correlation between productivity growth and ICT investment.

\section{(II) Reasons for Formation of ICT Productivity Paradox}

In the middle and late 1990s, the rapid development of ICT with Internet as the core has brought about the rapid popularization and application of Internet, and informatization has become a prominent feature of economic development in various countries, especially in developed countries. 
More and more academic researches show that the contribution rate of ICT investment to TFP and economic growth began to appear, and Solow (2000) indicated that "productivity paradox" has begun to disappear gradually. Foreign scholars tried to explain the possible causes of the "productivity paradox" from multiple aspects.

\section{Time delay effect theory}

The time delay effect theory refers that the ICT investment can drive the improvement of the TFP and economic growth. American economic historian David (1990) ${ }^{[13]}$ pointed out that it takes over 40 years from the invention of electric power in 1880 to the extensive application of electric power technologies in manufacturing industry in 1920 , and to the positive promotion of productivity in industry. When the diffusion level of a technology exceeds $50 \%$, it will obviously drive the productivity. Based on this, it takes time to give the driving effect of ICT on economic growth into full play. Kivij et al. (1995) ${ }^{[14]}$ organized studies on the relationship between ICT investment and performances of 200 large companies in Finland. The results show that there is not necessarily a correlation between the company's financial performance and ICT investment in short term, but ICT investment will produce high returns to the company's performance in the long run. Researches by Brynjolfsson and Hitt (2000) ${ }^{[15]}$, Zhang Zhiguang, Yu Rui and Shi Yaobo, et al (2014) ${ }^{[16]}$ also show that the long-term impact of ICT investment on economic growth is greater than its short-term impact.

\section{Measuring error theory}

The measuring error theory refers that most of incomes from ICT investment are ignored by the traditional GDP accounting method, which underestimates the increase of productivity in the field of ICT capital, thus resulting in paradox. Brynjolfsson and Hitt (1993) ${ }^{[17]}$ found via researches that in the manufacturing industry in the U.S., the marginal GDP of ICT exceeds 50\% every year, but the output indexes such as product quality, diversity, customization and response speed are neither measurable nor accurate. Most ofincomes from ICT investment are ignored by traditional accounting methods, thus resulting in systematic undervaluation of productivity.

\section{Theory of improper management}

The theory of improper management theory refers that the potential of ICT investment has been fully explored due to improper management of enterprises. Brynjolfsson and Hitt (1996) ${ }^{[18]}$ believed that enterprise's decision makers tend to invest in ICTs that are continuously inefficient for personal rather than corporate benefits, which does not contribute significantly to the improvement of enterprise's performance. His research done in 2000 shows that many enterprises do not make clear the motive of ICT investment, and they make ICT investment just by copying what others do without detailed cost and income analysis. They do not make appropriate adjustment to output target, work organization and incentive mechanism after investment, but still follow the original decisionmaking mode and criteria. Thus, the information system has not played its due role, and ICT investment constitutes a waste of enterprise resources.

\section{Capital stock theory}

Capital stock theory refers that although the ICT investment keeps growing rapidly, it contributes little to the economic growth due to its small proportion of capital stock in social capital stock. The research of Oliner \& Sichel (1994) ${ }^{[19]}$ shows that the contribution rate of ICT investment to economic growth in the U.S. from 1970 to 1992 is only $0.16 \%$ every year. The main reason is that the share of ICT capital is less than $2 \%$, and the share of factor income is relatively small. Only when the accumulation of ICT capital reaches a certain critical value, the contribution rate of ICT capital could accelerate the economic growth. In the middle and late 1990s, the mainstream views have recognized that the ICT investment brings great impetus to the increase of TFP and economic growth although some scholars still think that the growth of economy and the improvement of TFP are not inevitably the result of ICT development. From both enterprise and industry level, ICT has influence on the acceleration of economic growth, improvement of enterprise technologies, and innovation in business, management and organization structure.

\section{(III) Evolution and Development of ICT Productivity Paradox}

However, in the early 21st century, as the Internet bubble bursts and the ICT industry enters its adjustment stage, the business circles and academic circles started fierce discussion on the value of ICT. Gordon $(2000,2001){ }^{[20]}$ et al questioned the revolution of ICT in the context of the new economy. 
Arguing that the rapid growth of productivity in the 1990s was only the result of cyclical economic growth and not necessarily related to ICT investment. Carr's article published in Harvard Business Review in May 2003 brought the debate to a climax. He believed that the real strategic value and competitive advantage of the company's resources is scarcity rather than universality, and the ICT has changed from proprietary technology to basic technology, becoming an undifferentiated mass commodity like railway, electric power and other infrastructure as its capacity and popularity have matured, thus its strategic importance has been greatly reduced. However, in the initial stage of expansion, it is extensively recommended for its great business potential as a proprietary technology, thus attracting a large amount of capital investment. However, over-speed expansion will also result in increased competition, surplus productivity and reduced price, thus gradually weakening the enterprise's differential competitive advantages and increasing its economic burden. Therefore, the enterprise's ICT management should focus on reducing investment and avoiding risks, rather than seeking new opportunities.

Grover (2012) ${ }^{[21]}$ pointed out that economic growth in the U.S. faces stagnation due to resistance from cancellation of demographic dividend, rising education cost, excessive debt, increased income inequality, equalization of factor prices caused by globalization, and energy and environmental crises, so it is necessary to make innovation to cope with the economic decline. However, the technological innovation brought about by the computer and internet revolution cannot be compared with the previous two industrial revolutions whether in terms of intensity or growth potential. ICT triggered only a short recovery of the U.S. economy from 1996 to 2004, after which the growth fell to $1.33 \%$, and even $0.5 \%$ from 2010 to 2012 . Thus, he further predicted that it will be only $0.2 \%$ by 2010 . For example, according to the development trend of the second industrial revolution, the contribution of the "new economy" brought by the ICT to the productivity is only $13 \%$ of the contribution of the second industrial revolution to the productivity. Although many of the current innovations are enthusiastically popular among the people, only new opportunities for consumption are provided, rather than a continuation of the historical tradition of replacing human labor with machines. Therefore, the current technological innovation cannot fundamentally improve productivity and further boost the economic growth.

Acemoglu et al(2014) ${ }^{[22]}$ points out that, at a minimum, the "productivity paradox" can be still found at least in U.S.'s manufacturing industry. They found through researches that the growth of manufacturing productivity in the U.S.between 1980 and 2009 was largely driven by the computer manufacturing sector, and when these sectors were excluded, productivity growth in ICT-intensive industries has been weaker and weaker since the late 1990s. By 2009, there was little net growth in relative productivity. Therefore, they believed that it is too early to conclude that the "productivity paradox" has been resolved, and that more rigorous tests and evidences for the effect of ICT on productivity growth are needed. The academic circles organized more and deeper researches on productivity paradox as the ICT continuously develops. The research shows that the "productivity paradox" has stage characteristics and the ICT "productivity paradox" will exist to a certain extent in different stages of different developing countries and regions over time. Based on this, Dedrick and Kraemer (2000) and Pohjola (2000) et al. found through researches that productivity paradox is common to all countries in the course of ICT development. However, the "productivity paradox" produced by ICT has a certain threshold, thus making productivity paradox exist in different stages. Productivity paradox will be solved gradually once the development of ICT breaks through this threshold. Based on this vision, Wang Aimin (2015) ${ }^{[23]}$ studied the existence of productivity paradox in China's rural informatization based on the threshold panel regression model

\section{(IV) Hierarchical Analysis on Productivity Paradox}

At present, the domestic and foreign scholars mainly analyze productivity paradox from three layers of macroeconomy, industry and enterprise. From the enterprise level, the most diversified research results are obtained as the enterprise data can be easily obtained and is highly valued by the management personnel and scholars. Researches in this aspect mainly focus on the relationship between ICT investment and enterprise performance. Strassm an (1990) ${ }^{[24]}$ proposed some indexes for measuring enterprise performance, such as asset yield, net investment yield, economic added value, etc., and studied the impact of ICT investment on these indexes. Results show that there is no significant correlation between the ICT investment and enterprise performance, thus recognizing the existence of productivity paradox.

Brynjofsson and Hitt (1996) ${ }^{[18]}$ took the data of 367 companies in the U.S. from 1987 to 1991 as the sample to analyze the impact of information system expenditure on the enterprise's productivity. Results show that the productivity paradox did exist in the late 1980s, but disappeared in the early 1990s. Lin and Shao (2006) studied the relationship between the ICT investment and enterprise's productivity. 
Results show that the "productivity paradox" still existed, and that the same attention shall be paid although ICT capital could not completely substitute for labor. Wang Miaojun and Zhang Weiying (2007) ${ }^{[25]}$ studied the effect of ICT on enterprise performance from the microcosmic prospect. Results show that the ICT investment promotes the improvement of enterprise's productivity, competitiveness and innovation ability, and that the efficiency of ICT capital is far higher than that of non-ICT capital.

From the industry level, Stiroh (2002) ${ }^{[26]}$ examined the relationship between change in productivity growth rate and ICT capital accumulation of 61 industries in the U.S. in the 1990s that are weakly related to ICT equipment manufacturing, intensive use of ICT and revolution of ICT. Results show that productivity recovery in the late 1990s is very common in the U.S. Nearly two-thirds of the industries show a trend of accelerated productivity growth. ICT-intensive industries have higher levels of productivity than other industries. The ICT industry plays an important role in promoting the productivity growth of other industries. Stiroh believed that the use of ICT is an important component of productivity recovery in the U.S. and can bring real economic benefits. He criticized Gordon $(1999,2000)$ 's view that productivity recovery is mainly affected by the manufacturing of ICT equipment and cyclical factors. Nordhaus $(2001)^{[27]}$ found through researches that productivity growth in the non-new sectors was also substantially improved during the "new economy" period, especially in the industrial machinery manufacturing industry represented by computers and the electronic machinery manufacturing industry represented by semiconductors. It has promoted the growth of the ICT industry, and also boosted the technological improvement of other industrial sectors and the improvement of the overall economic productivity. From the perspective of macro-economy, Dewan and Kraemer (2000) ${ }^{[28]}$ studied the impact of ICT investment on developed and developing countries, taking data of 36 countries from 1985 to 1993 as samples. Results show that the "productivity paradox" only appeared in the developing countries, and there was no such phenomenon in the developed countries. Lee et al. (2005) ${ }^{[1]}$ organized researches using productivity of 20 countries from 1980 to 2000. Results show that ICT investment contributed to the improvement of the TFP in developed countries, while it didn't appear in developing countries. This is mainly due to the poor ICT infrastructures, high information input costandlow management level in developing countries. Raúl L. Katz et al. (2009) measured and analyzed the economic impact of ICT investment in Germany during2010-2014 and 2015-2020. Results show that the ICT investment between 2010 and 2014 brought GDP growth of 4.33 billion euros, while that brought by ICT

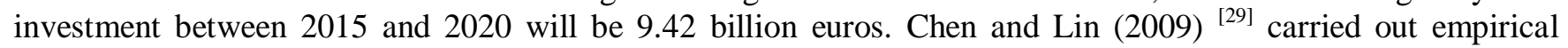
researches based on the input-output data of 15 countries from 1993 to 1999. Results show that the "productivity paradox" may appear not only in the developed countries but also in the developing countries. Hawash and Lang (2010) ${ }^{[30]}$ studied the relationship between ICT investment and TFP in 33 developing countries from 2002 to 2006. Results show that the application of ICT is the most important factor affecting the growth of the TFP in developing countries. Van Ark (2001) ${ }^{[31]}$, Lovrić L (2012) ${ }^{[32]}$ analyzed both developed and developing countries in Europe. Results show that investment in ICT has a positive impact on the growth of labor productivity in both developed and developing countries. From 1995 to 2001, there was little difference in the contribution rate of ICT investment between developed countries and developing countries to economic growth, but from 2001 to 2010, the difference in the contribution rate of ICT investment between developed countries and developing countries began to appear gradually.

At present, China's researches on ICT investment and "productivity paradox" are still in the initial stage. According to Li Zhitang's (2009) ${ }^{[33]}$ academic researches, from 2000 to 2008, there are a total of 34 academic papers in China with the topic covering "ICT investment", including 6 review articles (17.6\%), 15 theoretical analysis articles (44.1\%), 4 empirical research articles (11.8\%), and 9 general descriptive articles $(26.5 \%)$. Yu Liping (2012) ${ }^{[34]}$, Jing Fei and Yu Liping (2013) ${ }^{[35]}$ et al. studied China's economic growth and productivity growth from 1978 to 2009 . Researches show that the contribution of informatization is historically evolved. There existed productivity paradox in the early 10 years of China's reform and opening up, and information had negative contribution to the TFP and economic growth. With the popularization and development of ICT, the "productivity paradox" disappeared. Zhang Zhiguang, Zhao Xin and Kang Hua (2015) ${ }^{[36]}$ researched the impact of ICT on economic growth in developed and developing countries.

Results show that the improvement of the TFP in developed countries depends mainly on technological progress, while that of developing countries mainly on technological efficiency. From the point of view of technology efficiency, developed countries or regions mainly rely on scale efficiency, while developing countries mainly on technology efficiency only. ICT investment has significantly promoted the improvement of the TFP in developing countries, but may not obviously promote the improvement of the TFP in developed countries. 


\section{Research Review and Vision}

It is found by sorting relevant literatures that, as the research deepens and the information level rapidly develops, more and more scholars affirm the promotion effect of ICT investment on the TFP and economic growth. In the meantime, however, there is "productivity paradox" as well. ICT investment is influenced by time delay effect, measuring error and insufficient capital stock. There are "productivity paradox" of ICT to certain extent in countries and regions with different development levels, which features stage characteristics and threshold effects. When the development of ICT breaks through this threshold, the "productivity paradox" disappears, and the contribution of ICT investment to TFP and economic growth will be gradually highlighted. However, will the increasing ICT investment bring sustained impetus to the TFP and economic growth? Is there a "ceiling" for development, and when it exceeds the highest threshold, will the contribution rate of ICT investment to the TFP and economic growth show a marginal declining effect? These questions are still the hot issues concerned by the economists in the future.

\section{Bibliography}

OECD. ICT and economic growth: evidence from OECD countries, industries and firms[R]. Paris:OECD,2003.

Jorgenson D W, Stiroh K J, Gordon R J, et al. Raising the Speed Limit: U.S. Economic Growth in the Information Age[J]. Brookings Papers on Economic Activity, 2000, 2000(1):125-235.

Oliner\& Sichel. Information technology and productivity", Federal Reserve Bank of Atlanta Economic Review[J].2002, third quarter: $15-44$.

Jorgenson D. Information Technology and the U.S. Economy[M]. Taxation, technology, and the U.S. economy. Pergamon Press, 2001:1-32.

Zhong Genyuan, Wang Fanghua, Xing Xihuan, Information Technology, Economy Growth and Labor Productivity Growth [J], Journal of Industrial Engineering and Engineering Management, 2005,(04):1621.

Jorgenson D W, Ho M S, Stiroh K J. A Retrospective Look at the U.S. Productivity Growth Resurgence[J]. Journal of Economic Perspectives, 2008, 22(1):3-24.

Hawash R, Lang G. The Impact of Information Technology on Productivity in Developing Countries[C]// The German University in Cairo, Faculty of Management Technology, 2010.

Chang Y B, Gurbaxani V. The Impact of IT-Related Spillovers on Long-Run Productivity: An Empirical Analysis[M]. INFORMS, 2012.

Huang P, Ceccagnoli M, Forman C, et al. IT Knowledge Spillovers and Productivity: Evidence from Enterprise Software[J]. Ssrn Electronic Journal, 2013.

Roach S. America's technology dilemma: a profile of the information economy[J]. Zeitschrift Angewandte Mathematik Und Mechanik, 1987, 78(Supplement S3):973-974.

Solow, R.M..”we'd better watch out", New York Times Book Review, 1987,July 12,36.

Berndt E R, Morrison C J. High-tech capital formation and economic performance in U.S. manufacturing industries An exploratory analysis [J]. Working Papers, 1992, 65(1):9--43.

David P A. The Dynamo and the Computer: An Historical Perspective on the Modern Productivity Paradox[J]. American Economic Review, 1990, 80(2):355-361.

Kivij, Rvi H, Saarinen T. Investment in information systems and the financial performance of the firm[M]. Elsevier Science Publishers B. V. 1995.

Brynjolfsson E, Hitt L M. Beyond the productivity paradox[J]. European Journal of Information Systems, 2000, 9(2):128-128.

Zhang Zhiguang, Yu Rui and Shi Yaobo, The Information Technology Investments and Chinese Economic Growth: An Analysis Based on Vector Auto Regression Model [J], System Engineering, 2014,(05):75-81.

Brynjolfsson E. The productivity paradox of information technology[M]. ACM, 1993.

Brynjolfsson E and L. Hitt, Paradox lost? Firm-level evidence on the returns to information systems spending, Management Science 42 (1996) 541-558.

Oliner S D, Sichel D E, Triplett J E, et al. Computers and Output Growth Revisited: How Big is the Puzzle?[J]. Brookings Papers on Economic Activity, 1994, 1994(2):273-334.

Gordon R J. Technology and Economic Performance in the American Economy[J]. Cepr Discussion Papers, 2002. 
Grover V, Kohli R. Cocreating IT value: new capabilities and metrics for multifirm environments[M]. Society for Information Management and The Management Information Systems Research Center, 2012.

Acemoglu D, Autor D H, Dorn D, et al. Return of the Solow Paradox? It, Productivity, and Employment in U.S. Manufacturing[J]. Social Science Electronic Publishing, 2014, volume 104(5):394-399(6).

Wang Aimin, Is There a "Productivity Paradox" in China's Rural Informatization? - A Test Based on Threshold Panel Regression Model. [J]. China Soft Science,2015,(07):42-51.

Strassmann P A. Information payoff; the transformation of work in the electronic age[J]. Clinical Cornerstone, 2011, 3(1):66-72.

Wang Miaojun, Zhang Weiying and Zhou Lian, Information Technology OrganizationalInnovation Productivity Evidence on the Phase Characteristics of Complementarities[J]. Economic Research Journal,2006,(01):65-77.

Stiroh K J. Information Technology and the U.S. Productivity Revival: What Do the Industry Data Say?[J]. American Economic Review, 2002, 92(5):1559-1576.

Nordhaus W D. Productivity Growth and the New Economy[J]. Brookings Papers on Economic Activity, 2002, 2002(2):211-244.

Dewan S, Kraemer K L. Information Technology and Productivity: Evidence from Country-Level Data[J]. Management Science, 2000, 46(4):548-562.

Lee S Y T, Gholami R, Tong T Y. Time series analysis in the assessment of ICT impact at the aggregate level lessons and implications for the new economy[J]. Information \& Management, 2005, 42(7):1009-1022.

Hawash R, Lang G. The Impact of Information Technology on Productivity in Developing Countries[C]/The German University in Cairo, Faculty of Management Technology, 2010.

van Ark, B. The renewal of the old economy: Aninternational comparative perspective[J]. OECD Science, Technology and Industry Working Papers.2001.

Lovrić L. Information-Communication Technology Impact on Labor Productivity Growth of EU Developing Countries[J]. Zbornik Radova Ekonomskog Fakulteta U Rijeci Časopis Za Ekonomsku Teoriju I Praksu, 2012, 30(2):223-245.

Li Zhitang.Research on Information Technology Investment Performance Based on Complementary Theory[J]. Science Research Management,2009,(01):8-14+27.

Yu Liping. A Study on the Interactive Relationship between Inter-provincial Informatization and Financial Development in China: Study on Informatization and Finance Based on Panel VAR [J]. Journal of Central South University (Social Science Edition),2012,(03):110-115.

Jing Fei, Yu Liping. On Productivity Paradox of Informatization and Economy Growth [J]. Journal of Intelligence,2013,(03):203-207.

Zhang Zhiguang, Zhao Xin and Kang Hua, IT Investments and Productivity Paradox: The Comparison between the Developed Countries and the Developing Countries[J]. Future and Development, 2015,(07):25-30+5. 